\title{
THERMAL PERFORMANCE OF A GLASS BALL SOLAR COOKER
}

\author{
Ragab I. A. Mourad \\ Soils and Water Dept., Fac. of Agric., Fayoum University.
}

\begin{abstract}
A glass ball solar cooker (GBSC) with and without reflector dish was employed to utilize the energy in cooking process. Some variables were investigated to evaluate the GBSC performance, (solar intensity, ambient air temperature, wind speed and relative humidity). The performance was characterized by water temperature within the cooker vessel, with and without reflector dish. Thermal analysis was applied in GBSC with reflector dish to study the solar radiation behavior within GBSC. A statistical model, based on step-wise regression analysis revealed significant relationships between these variables at the level of 0.001 significance, except relative humidity was not significant. Results showed that, water $(1 \mathrm{~kg})$ in vessel cooker needs 90 minute to boil at $100{ }^{\circ} \mathrm{C}$, while $0.5 \mathrm{~kg}$ of rice needs 165 minute to cook, with the reflector dish. The maximum efficiency of GBSC was about $23.6 \%$.
\end{abstract}

Key Words: Solar cooker - reflector dish - intensity - concentrating cooker.

\section{ITERODUCTION}

The serious problems associated with fuel-burnings cooker, the shortage of wood supplies, and the high cost of fuel have raised the need for alternative sources of energy saving and safe cookers. Solar cookers offer a simple, safe, and pollution free alternative. A number of designs using different concepts have been presented for indoor and outdoor usages. The most widely know type of solar cookers is the portable box-type oven, with solar radiation entering the oven directly through the transparent top cover, and also by reflection from plain mirrors.

Many researchers have been interested with the solar cookers (Mullick et al. 1987; Osman 1980; Funk and Larson 1998 and Biermann et al. 1999). Das et al. (1994a) used the solar box-cookers to cook rice, vegetables, meat, bake-cakes, and prepare a variety of other items. The cooking time ranged from 1 to $2.5 \mathrm{hr}$, or the cooker may fail to cook depending on the intensity of solar radiation and the number of vessels in the cooker. Grupp et al. (1991) presented a novel design of the box-cooker in which the cooking vessel was set into the glazing. This arrangement affords a good thermal contact between the vessel and the absorber plate, easier access to the vessel, and less frequent maintenance of the cooker. Ibrahim and

Fayoum J. Agric. Res. \& Dev., Vol. 21, No.1, January, 2007 
Khalifa (1988) reported that, the smaller cookers perform are better than the large size cookers due to the increasing of the thermal mass of the large ones.

A number of computer models have been developed to predict the thermal performance of different types of solar cookers. Grupp et al. (1991) presented a finite-element model for the cooker, and highlighted the importance of the thermal contact between the vessel and the absorber plate. Das et al. (1994a) and Das et al. (1994b) simulated the thermal performance of a solar box with horizontal glazing, reflecting mirror, and aluminum absorber plate and containing one, two or four vessels. Three dimensional, unsteady-state heat condition equations with time dependent radiation, convection, and conduction boundary conditions were used. Two other solar box-cooker performance models were presented by Khalifa et al. (1986). Habeebullah et al. (1995) studied the prediction of cooking temperatures and heat-up rates for concentrating solar cookers with different wind speeds and cooking strategies. Applications of this model like wise seems limited to very similar concentrating cookers.

This paper presents a simple glass ball solar cooker with reflector dish. The main objectives of the present study are;

1- To study the effects of the metrological conditions on the cooker thermal performance.

2- To study the thermal behavior with the glass ball cooker with the reflector dish.

\section{MATERIALS AND METHODS}

The experimental work was started at March and carried out through April, May, June, July and August 2006. Four days of experimental records were taken from every month as the best meteorological conditions.

Description of the glass solar cooker (GBSC):

Fig. (1) shows a sketch of a glass ball solar cooker (GBSC). The GBSC consists of an empty glass ball of $35 \mathrm{~cm}$ diameter and $3 \mathrm{~mm}$ glass thickness. The glass ball has an upper orifice of $15 \mathrm{~cm}$ diameter, which was provided with glass cover. A black aluminum cylindrical vessel $(12 \mathrm{~cm}$ in diameter, $20 \mathrm{~cm}$ in high and $0.5 \mathrm{~mm}$ thickness) was placed inside the glass ball. The vessel was provided with a tight-foil aluminum cover. The GBSC was placed on a reflector dish of $80 \mathrm{~cm}$ diameter and $15 \mathrm{~cm}$ depth. A cylindrical wood of $15 \mathrm{~cm}$ diameter and $10 \mathrm{~cm}$ high was placed under the glass ball. Collected data (ambient air temperature $\left(\mathrm{T}_{\mathrm{a}}\right.$ ), gap (distance between the vessel and the glass) temperature ( $\left.T_{\text {gap }}\right)$, vessel temperature $\left(T_{v}\right)$ and food temperature inside the vessel $\left(T_{f}\right)$ were recorded hourly using data logger (VE310), which had an accuracy of 0.1.

Thermal behavior within the glass ball with the reflector dish:

Fayoum J. Agric. Res. \& Dev., Vol. 21, No.1, January, 2007 


\section{THERMAL PERFORMANCE OF A GLASS BALL SOLAR COOKER.143}

As shown in Fig. (1), solar radiation reaches to the glass ball directly and by reflection from the reflector dish. The glass absorbs part of the solar radiation falling on its surface $\left(\alpha_{\mathrm{g}} \mathrm{R} \mathrm{A}_{\mathrm{b}} \eta_{\mathrm{ref}}\right)$, and transmits part inside the glass ball $\left(\tau_{\mathrm{g}} \mathrm{RA} \mathrm{b}_{\mathrm{b}} \eta_{\text {ref }}\right)$, which is used in heating the vessel and its contents $\left(\alpha_{s} \tau_{g} R A_{v} \eta_{\text {ref }}\right)$. The rest is lost in the form of radiation $\left(q_{r}\right)$ and convection $\left(q_{c}\right)$ to the surroundings. The using energy in heating vessel contents is equaled $\left(\mathrm{q}_{\mathrm{f}}\right)$. There is a lost energy from the vessel to the glass ball $\left(\mathrm{q}_{\mathrm{v}}\right)$.

Where:

$\mathrm{R}$ is the solar radiation intensity in $\mathrm{W} / \mathrm{m}^{2}$,

$A_{b}$ is the projected area of the glass ball in $\mathrm{m}^{2}$,

$A_{v}$ the vessel area, which receives the radiation $\left(A_{v}=(\pi / 4) D^{2}+\pi D L\right)$ in $m^{2}$

$\mathrm{D}$ is the vessel diameter and $\mathrm{L}$ is the vessel height in $\mathrm{m}$,

$\alpha_{\mathrm{g}}$ is the glass absorbativity, $(0.1)$

$\alpha_{v}$ is the black painted aluminum absorbativity, (0.85)

$\tau_{\mathrm{g}}$ is the glass transmisivity, $(0.88)$

$\eta_{\text {ref }}$ reflector efficiency, $\left[\eta_{\text {ref }}=\left\{1+(\mathrm{CR}-1) \rho_{\text {ref }}\right\} / C R\right]$

$\mathrm{CR}$ is the concentration ratio $=3.5, \rho_{\text {ref }}$ is the reflectivity $=0.78,($ Ibrahim $\&$

Khalifa,1988).

$\mathrm{q}_{\mathrm{r}}$ is the lost energy by radiation to the surrounding in $\mathrm{W}$,

$\mathrm{q}_{\mathrm{c}}$ is the lost energy by convection to the surrounding in $\mathrm{W}$,

$\mathrm{q}_{\mathrm{v}}$ is the lost energy from the vessel to the glass ball in $\mathrm{W}$,

$\left[\mathrm{q}_{\mathrm{v}}=\mathrm{h}_{\mathrm{v}-\mathrm{gap}} \mathrm{A}_{\mathrm{v}}\left(\mathrm{T}_{\mathrm{v}}-\mathrm{T}_{\mathrm{g}}\right)\right]$,

$\mathrm{h}_{\mathrm{v} \text {-gap }}$ is the convection heat transfer coefficient between the vessel and the glass ball gap in $\mathrm{W} / \mathrm{m}^{2 \mathrm{O}} \mathrm{C}$.

$\mathrm{q}_{\mathrm{f}}$ is the instantaneous heat stored in the fluid in $\mathrm{W}$.

From the previous assumptions the instantaneous cooker efficiency is defined as $\eta=\mathrm{q}_{\mathrm{f}} /\left(\mathrm{R} \mathrm{A}_{\mathrm{b}} \eta_{\mathrm{ref}}\right)$

This efficiency is a function of time since both $\mathrm{q}_{\mathrm{f}}$ and $\mathrm{R}$ are timedependent variables. So, final form of the cooker efficiency is

$$
\eta=(\mathrm{mc})_{\mathrm{f}}\left(\mathrm{T}_{\mathrm{fmax}}-\mathrm{T}_{\mathrm{fi}}\right) /\left(\mathrm{R} \mathrm{A} \mathrm{A}_{\mathrm{b}} \eta_{\text {ref }} \Delta \mathrm{t}\right)
$$

where, $\mathrm{m}$ is the mass of vessel component in $\mathrm{kg}, \mathrm{c}$ is the specific heat of the component material within the cooker vessel in $\mathrm{J} / \mathrm{kg}{ }^{\circ} \mathrm{C}, \mathrm{T}_{\text {fmax }}$ is the maximum temperature of the vessel component in ${ }^{\circ} \mathrm{C}, \mathrm{T}_{\mathrm{fi}}$ is the initial temperature of the vessel component in ${ }^{\circ} \mathrm{C}$, $\mathrm{t}$ is the required time to reach $\mathrm{T}_{\mathrm{fmax}}$ in minutes. 
1- Glass ball

2. Glass cover

3- Aluminum vessel

4- Aluminum foil cover

5- Wooden base

6- Reflector dish

7. Wooden legs

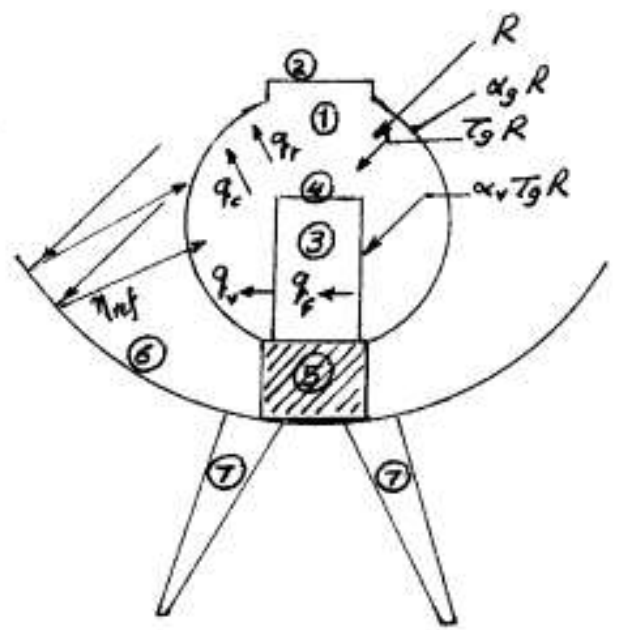

Fig.(1): Schematic diagram of the glass ball solar cooker with solar radiation behavior

\section{RESULTS AND DISCUSSION \\ Effect of solar intensity (R):}

Fig. (2) shows the effect of solar intensity on water temperature, with and without reflector dish. The water temperature increased as the solar intensity increased. Generally, it was clear that, the increasing of the solar intensity from 475 to $675 \mathrm{~W} / \mathrm{m}^{2}$ with $42.1 \%$, increasing the water temperature from 50 to $67^{\circ} \mathrm{C}$ with $34 \%$ for cooking without reflector dish, and from 63 to $86^{\circ} \mathrm{C}$ with $36.5 \%$ for cooking with reflector dish. Also, the reflector dish caused increasing the water temperature from the ambient temperature of $22^{\circ} \mathrm{C}$ (which, equal the initial water temperature) to $86^{\circ} \mathrm{C}$ with $291 \%$ in 84 minutes.

It also, indicated that, as ambient air temperature increased, the water temperature is increased.

Microsoft Excel 2000 was used to examine the relationship between the water temperature and the intensity of solar radiation with and without reflector. The obtained equations for the best fit were:

Where:

$$
\begin{array}{ll}
\mathrm{T}_{\mathrm{wi}}=0.0943 \mathrm{R}+21.60 & \mathrm{R}^{2}=0.97 \\
\mathrm{~T}_{\mathrm{wo}}=0.0654 \mathrm{R}+21.60 & \mathrm{R}^{2}=0.94
\end{array}
$$

$\mathrm{T}_{\mathrm{wi}}$ is the water temperature with the reflector dish in ${ }^{\circ} \mathrm{C}$,

$\mathrm{T}_{\mathrm{wo}}$ is the water temperature without the reflector dish in ${ }^{\circ} \mathrm{C}$,

$\mathrm{R}$ is the solar radiation intensity in $\mathrm{W} / \mathrm{m}^{2}$.

\section{Effect of wind speed $(W)$ :}

Fayoum J. Agric. Res. \& Dev., Vol. 21, No.1, January, 2007 
THERMAL PERFORMANCE OF A GLASS BALL SOLAR COOKER.145

Effect of wind speed on water temperature with and without reflector dish is represented in Fig. (3). The water temperature appears to decrease as the wind speed is increased. Whereas, the decreasing of wind speed from 20.5 to $8.5 \mathrm{~km} / \mathrm{hr}(58.5 \%)$, caused in increasing the water temperature from 53 to $64^{\circ} \mathrm{C}(20.8 \%)$ for cooking without reflector dish, and from 69 to $82^{\circ} \mathrm{C}$ (18.8\%) for cooking with reflector dish.

Data was fitted using Microsoft Excel and the following equations were resulted:

$$
\begin{array}{ll}
\mathrm{T}_{\mathrm{wi}}=169.25 \mathrm{~W}^{-0.3164} & \mathrm{R}^{2}=0.86 \\
\mathrm{~T}_{\mathrm{wo}}=127.21 \mathrm{~W}^{-0.3023} & \mathrm{R}^{2}=0.81
\end{array}
$$

Where: $\mathrm{W}$ is the wind speed in $\mathrm{km} / \mathrm{hr}$.

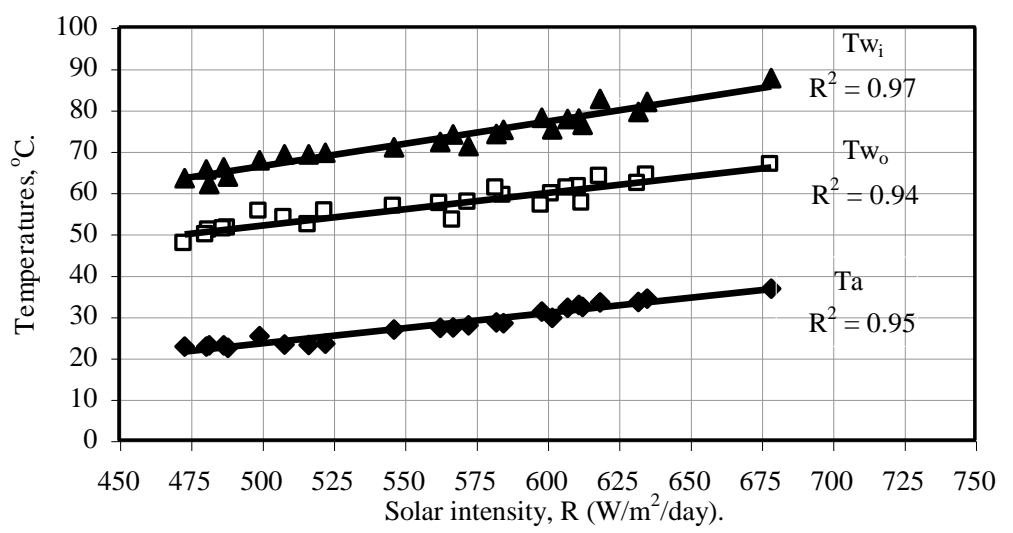

Fig. ( 2 ): Effect of Solar intensity on water temperature within the vessel, with \& without the reflector dish.

Fayoum J. Agric. Res. \& Dev., Vol. 21, No.1, January, 2007 


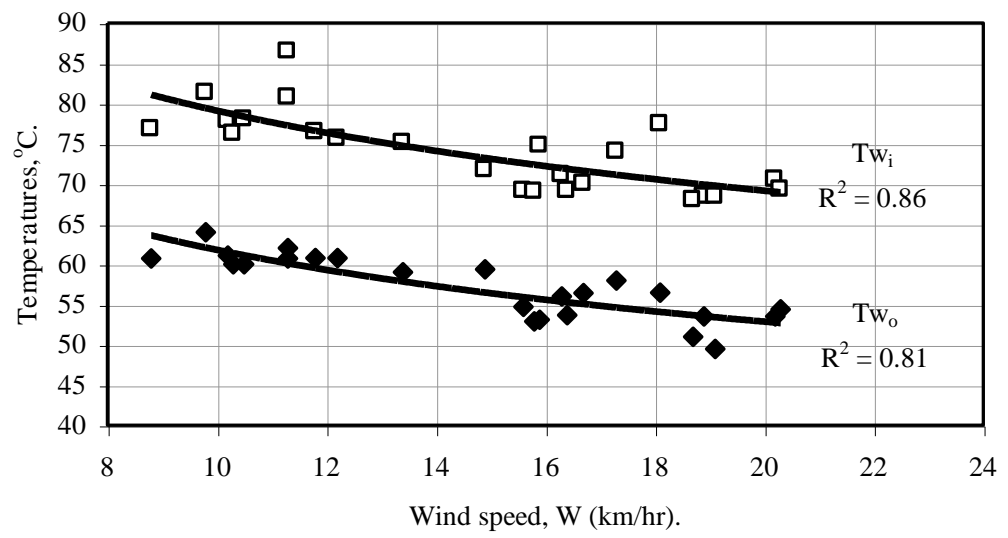

Fig.( 3 ): Effect of wind speed on water tempreature within the cooking vessel, with \& without the reflector dish.

\section{Effect of air relative humidity $(\mathrm{Rh})$ :}

Effect of air relative humidity was pronounced on the water temperature in the cooking vessel as shown in Fig. (4). Littleness of increasing the water temperature was observed by decreasing air relative humidity with and without reflector dish. Whereas, the change of air relative humidity from $84 \%$ to $72 \%$ (14.3\%), caused in increasing water temperature from 56 to $68^{\circ} \mathrm{C}(3.6 \%)$ for cooking without reflector dish, and from 74 to $75^{\circ} \mathrm{C}(1.4 \%)$ for cooking with reflector dish.

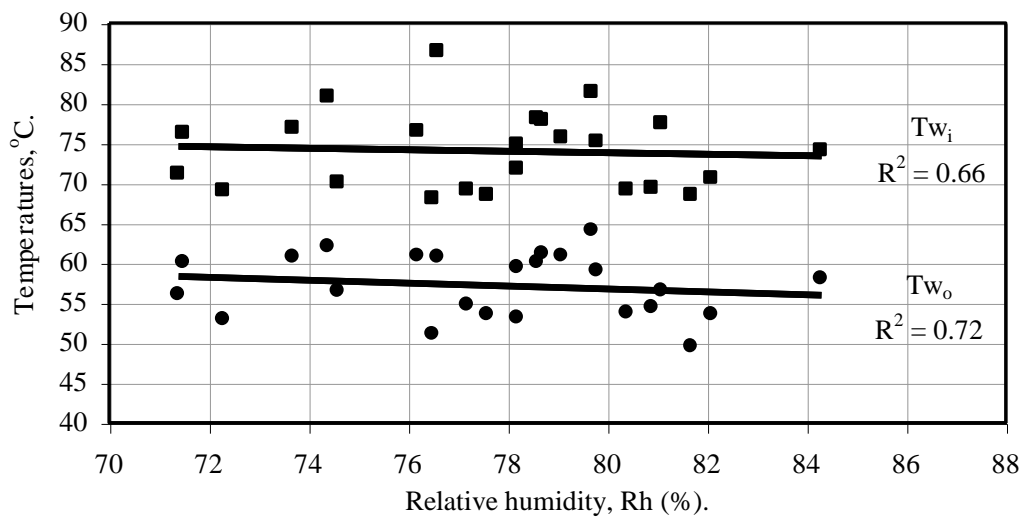

Fig. ( 4 ):Effect of relative humidity on water temperature within the cooking vessel, with \& without the reflector dish.

\section{Statistical analysis:}

Fayoum J. Agric. Res. \& Dev., Vol. 21, No.1, January, 2007 


\section{THERMAL PERFORMANCE OF A GLASS BALL SOLAR COOKER.147}

Effect of individual variables \{solar intensity (R), ambient temperature (Ta), wind speed (W), and air relative humidity $(\mathrm{Rh})\}$ were statistically analyzed. A simple statistical program was developed, utilizing the SAS statistical package. The forward step-wise regression analyses were applied to arrive at a reasonably good best set of independent variables. The multiple regression equations were:

$$
\begin{aligned}
& \mathrm{T}_{\mathrm{wi}}=2.41+0.0915 \mathrm{R}+0.541 \mathrm{~T}_{\mathrm{a}}-0.1937 \mathrm{~W} \\
& \mathrm{~T}_{\mathrm{wo}}=4.24+0.0719 \mathrm{R}+0.381 \mathrm{~T}_{\mathrm{a}}-0.2003 \mathrm{~W}
\end{aligned}
$$

The model shown that, the relationships between these parameters were highly significant $\left(\mathrm{R}^{2}=0.98\right.$ and $\left.\mathrm{P} \geq 0.001\right)$.

The coefficient of determination $\mathrm{R}^{2}$ for the final model was 0.9

To evaluate the GBSC, a linear regression model was developed to observe and predict water temperatures, with and without reflector dish. The graphical comparison of the observed versus predicted water temperature is presented in Figs. (5) and (6).

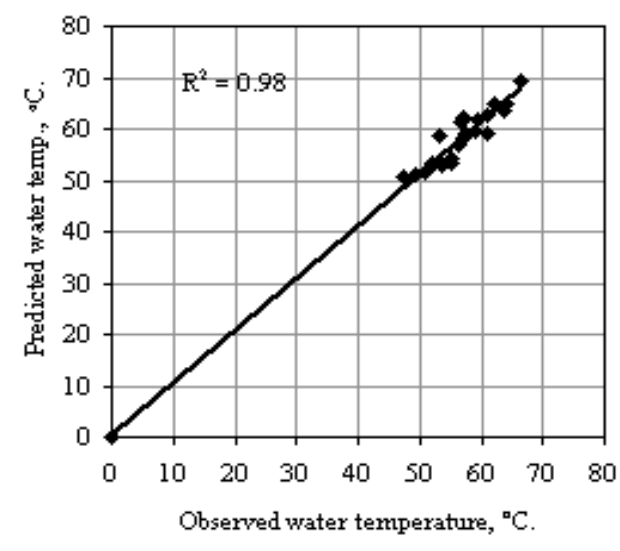

Fig.(S): Observed versus predicted water temperature without reflector dish.

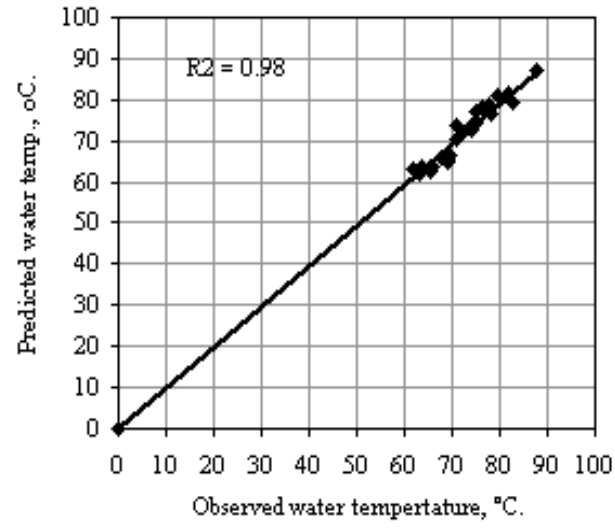

Fig.(6): Observed versus predicted water temperature with reflector dish.

\section{The glass ball solar cooker (GBSC) efficiency:}

As resulted from the previous thermal analysis, Fig. (7) shows the effect of solar time on vessel, fluid and gap temperature and GBSC efficiency during the experimental duration (as the best fit from the Microsoft Excel 2000 software). It's clear that, both of vessel and fluid increase with solar time increases. Similarly increasing of gap temperature with solar time. Water boiled after about 90 minute, while, the vessel temperature was over $100^{\circ} \mathrm{C}$, and gap temperature was about $66^{\circ} \mathrm{C}$, whereas, the initial water temperature was 22.3 , solar intensity was $467.4 \mathrm{~W} / \mathrm{m}^{2}$, ambient air temperature was $24.2^{\circ} \mathrm{C}$ and wind speed was $11.3 \mathrm{~km} / \mathrm{hr}$.

Fayoum J. Agric. Res. \& Dev., Vol. 21, No.1, January, 2007 
Ragab I. A. Mourad

On the other hand, the cooker efficiency decreased as solar time is increased. After ten minutes from the beginning of the experiment the efficiency reached to $23.6 \%$ and water temperature reached to $50^{\circ} \mathrm{C}$ from initial water temperature of 22.3 (124.2\% in water temperature increasing). While, increasing water temperature from $50{ }^{\circ} \mathrm{C}$ to $100{ }^{\circ} \mathrm{C}(100 \%$ in water temperature increasing) needed 80 minutes (800\% in solar time increasing), which, caused in deceasing of the cooker efficiency to become $13.7 \%$.

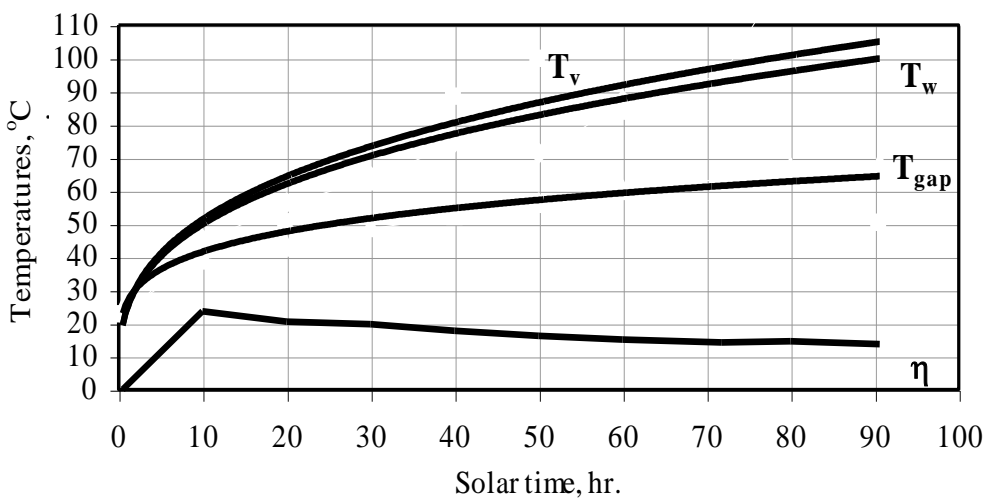

Fig. (7): Effect of solar time on vessel, fluid within vessel and the gap temperatures

\section{Cooking experiments}

The GBSC was tested for cooking actual food. In cooking with solar cooker, the weight of the food and its water content need to be considered. The cooking times on GBSC are given in Table (1).

Table (1). Cooking experiments for rice and eggs

\begin{tabular}{|l|c|c|c|c|}
\hline \multicolumn{1}{|c|}{ Food } & $\begin{array}{c}\text { Time of cooking } \\
(\text { minutes })\end{array}$ & $\begin{array}{c}\text { Solar } \\
\text { intensity } \\
\left(\mathrm{W} / \mathrm{m}^{2}\right)\end{array}$ & $\begin{array}{c}\text { Ambient } \\
\text { temp. } \\
\left({ }^{\circ} \mathrm{C}\right)\end{array}$ & $\begin{array}{c}\text { Wind } \\
\text { speed } \\
(\mathrm{Km} / \mathrm{hr})\end{array}$ \\
\hline Water (1 kg) & Boiling at 90 & 467.4 & 24.2 & 11.3 \\
Rice (0.5 kg) & 165 & 516.5 & 30.4 & 9.2 \\
Eggs (without water) & 175 & 524.6 & 30.8 & 10.8 \\
Eggs (with water) & 195 & 534.1 & 32.6 & 9.3 \\
\hline
\end{tabular}

\section{CONCLUSION}

A glass ball solar cooker is examined for cooking with and without reflector dish. The results showed that, the GBSC with reflector dish cooked rice and eggs within 2 to $3 \mathrm{hrs}$. On the other hand the GBSC without reflector dish failed to cook depending on the intensity of solar radiation reflected

Fayoum J. Agric. Res. \& Dev., Vol. 21, No.1, January, 2007 
THERMAL PERFORMANCE OF A GLASS BALL SOLAR COOKER.149 from the dish. The cooker efficiency is a function of time since both $\mathrm{q}_{\mathrm{f}}$ and $\mathrm{R}$ are time-dependent variables. So, the final form of the cooker efficiency is $\eta$ $=(\mathrm{mc})_{\mathrm{f}}\left(\mathrm{T}_{\mathrm{fmax}}-\mathrm{T}_{\mathrm{fi}}\right) /\left(\mathrm{R} \quad \mathrm{A}_{\mathrm{b}} \eta_{\text {ref }} \Delta \mathrm{t}\right)$. Results of the cooker efficiency are wakened, so further studies are needed to increase the GBSC efficiency.

\section{REFERENCES}

Biermann E., M. Grupp and R. Palmer (1999). Solar cooker acceptance in South Africa Results of a compartive field-test. Solar Energy 66 (1), 401-407.

Das T. C., S. Karmaker and D. P. Rao (1994a). Solar box-cooker. Part Imodeling. Solar Energy 52 (3), 265-272.

Das T. C., S. Karmaker and D. P. Rao (1994b). Solar box-cooker. Part IIanalysis and simulation. Solar Energy 52 (3): 273-283.

Funk P. A and D. L. Larson (1998). Parametric model of solar cooker perfor-mance. Solar Energy 62 (1), 63-68.

Grupp M., P. Montagne and M. Wackernagel (1991). A novel advanced box type solar Cooker. Solar energy 47, 107-113.

Habeebullah M. B., A. M. Khalifa and I. Olwi (1995). The oven receiver: an approach Toward the revival of concentrating solar cookers. Solar Energy 54 (4), 227-237.

Ibrahim A.O. and A. M. Khalifa (1988). Computer simulation of the solar pressure cooker. Solar Energy 40 (3), 259-268.

Khalifa A. M, M. M. Taha and M. Akyurt (1986). Cookers for solar homes. Applied Energy 24, 77-89.

Mullick S.C., T. C. Kandpal and A. K.Saxena (1987). Thermal test procedure for box type. Solar cooker. Solar Energy 39, 353-360.

Osman M. G. (1980). Solar energy for cooking in Egypt. Solar Energy 4, 1786-1795.

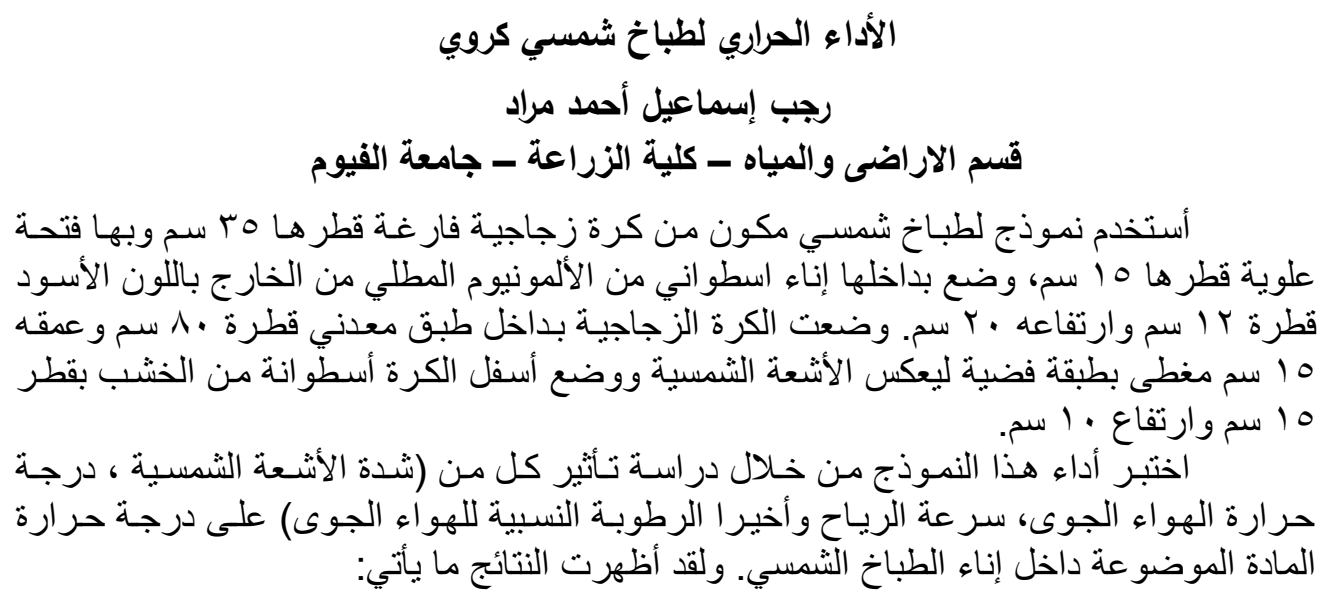

Fayoum J. Agric. Res. \& Dev., Vol. 21, No.1, January, 2007 
Ragab I. A. Mourad

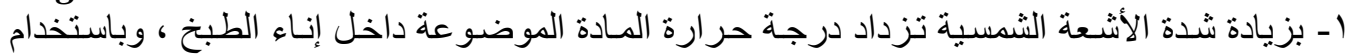

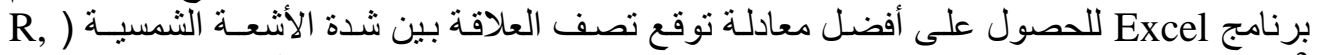

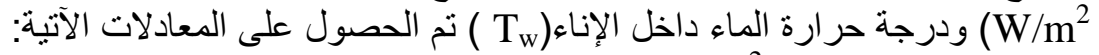

$$
\begin{array}{ll}
\mathrm{T}_{\mathrm{wi}}=0.0943 \mathrm{R}+21.60 & \mathrm{R}^{2}=0.97 \\
\mathrm{~T}_{\mathrm{wo}}=0.0654 \mathrm{R}+21.60 & \mathrm{R}^{2}=0.94
\end{array}
$$

حيث T درجة حر ارة الماء للطبخ عند استعمال عاكس شمسي

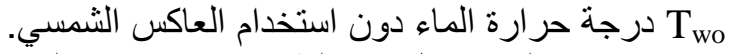

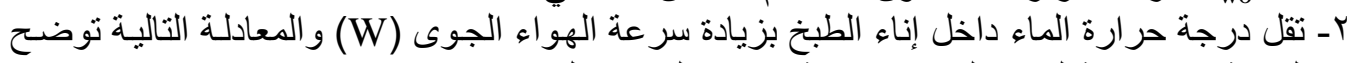

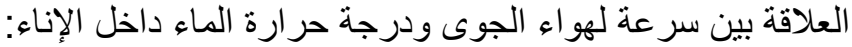

$$
\begin{array}{ll}
\mathrm{T}_{\mathrm{wi}}=169.25 \mathrm{~W}^{-0.3164} & \mathrm{R}^{2}=0.86 \\
\mathrm{~T}_{\mathrm{wo}}=127.21 \mathrm{~W}^{-0.3023} & \mathrm{R}^{2}=0.81
\end{array}
$$

rـ لم يكن هنالك تأثثرا قوي للرطوبة النسبية للهو اء الجوى على درجة حرارة الماء وعلى أداء الطباخ

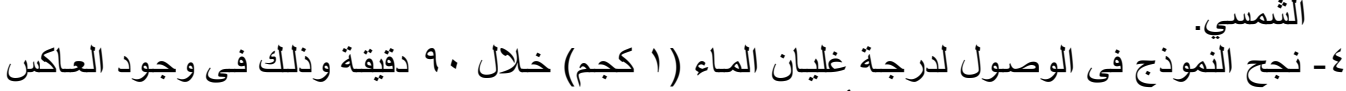

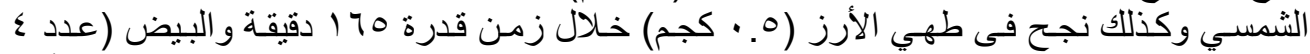

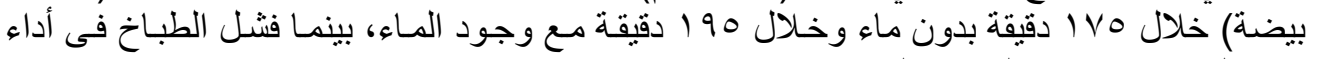

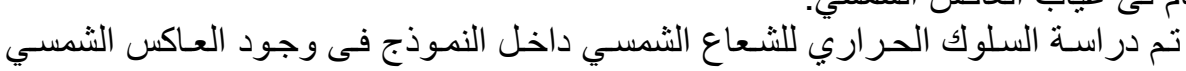

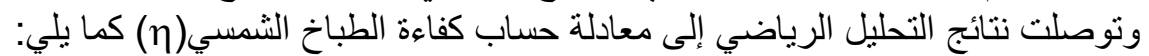

$$
\eta=(\mathrm{mc})_{\mathrm{f}}\left(\mathrm{T}_{\mathrm{fmax}}-\mathrm{T}_{\mathrm{fi}}\right) /\left(\mathrm{R} \mathrm{A} \mathrm{A}_{\mathrm{b}} \eta_{\mathrm{ref}} \Delta \mathrm{t}\right)
$$

حيث m وزن المادة داخل الإناء بالكيلوجرام، c الحرارة النوعية للمـادة داخل الإنـاء بالجول/كجم.

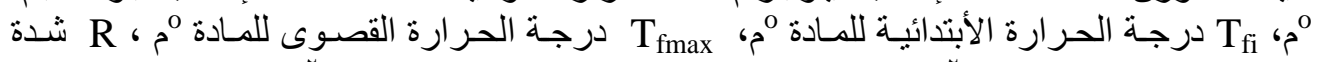

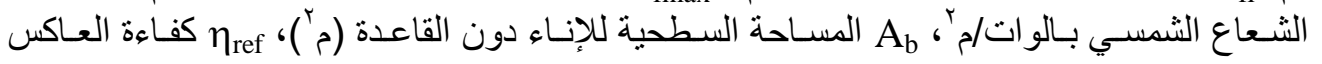

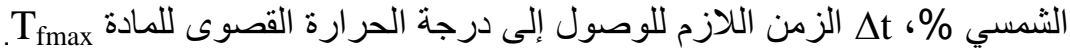

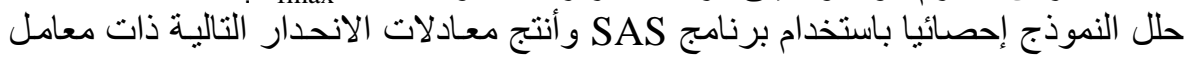

$$
\begin{aligned}
& \mathrm{T}_{\mathrm{wi}}=2.41+0.0915 \mathrm{R}+0.541 \mathrm{~T}_{\mathrm{a}}-0.1937 \mathrm{~W} \\
& \mathrm{~T}_{\mathrm{wo}}=4.24+0.0719 \mathrm{R}+0.381 \mathrm{~T}_{\mathrm{a}}-0.2003 \mathrm{~W} \\
& \text { حيث Ta درجة حرارة الهواء الجوى مَ م. }
\end{aligned}
$$

Fayoum J. Agric. Res. \& Dev., Vol. 21, No.1, January, 2007 